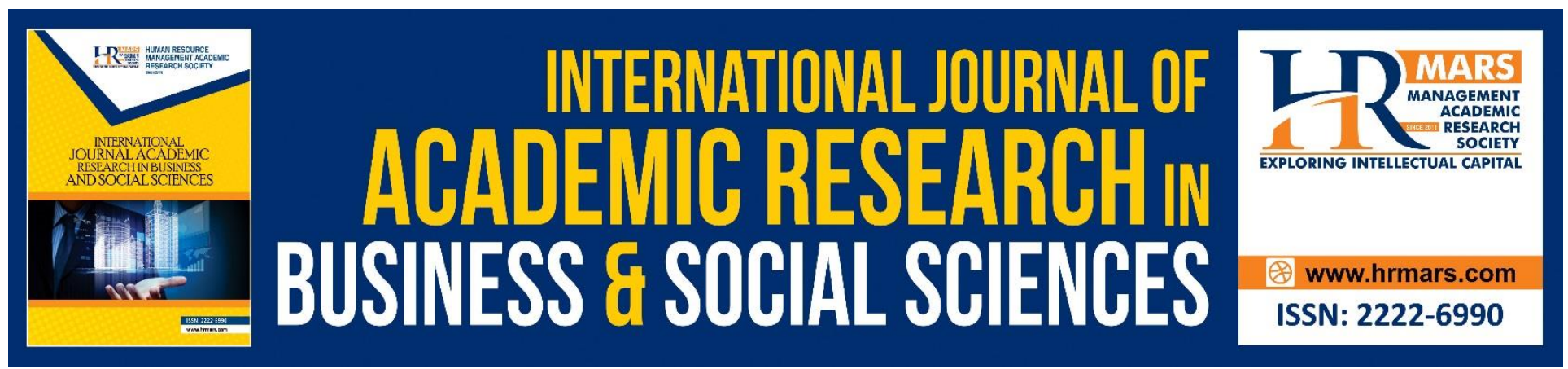

\title{
A Network-Based Approach for Emerging Rural Social Entrepreneurship
}

Seyedali Ahrari, Steven Eric Krauss, Zaifu Ariffin, Lee Kwan Meng

To Link this Article: http://dx.doi.org/10.6007/IJARBSS/v8-i9/4608

DOI: $\quad 10.6007 /$ IJARBSS/v8-i9/4608

Received: 06 August 2018, Revised: 27 August 2018, Accepted: 29 Sept 2018

Published Online: 15 October 2018

In-Text Citation: (Ahrari, Krauss, Ariffin, \& Meng, 2018)

To Cite this Article: Ahrari, S., Krauss, S. E., Ariffin, Z., \& Meng, L. K. (2018). A Network-Based Approach for Emerging Rural Social Entrepreneurship. International Journal of Academic Research in Business and Social Sciences, 8(9), 493-513.

Copyright: (C) 2018 The Author(s)

Published by Human Resource Management Academic Research Society (www.hrmars.com)

This article is published under the Creative Commons Attribution (CC BY 4.0) license. Anyone may reproduce, distribute, translate and create derivative works of this article (for both commercial and non-commercial purposes), subject to full attribution to the original publication and authors. The full terms of this license may be seen at: http://creativecommons.org/licences/by/4.0/legalcode

Vol. 8, No. 9, September 2018, Pg. 493 - 513

Full Terms \& Conditions of access and use can be found at http://hrmars.com/index.php/pages/detail/publication-ethics 


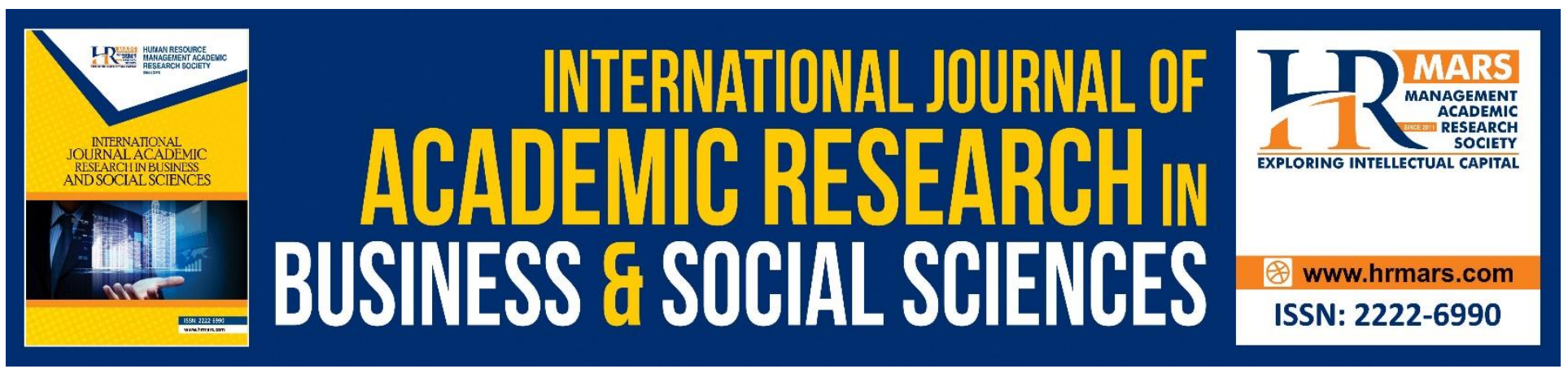

\title{
A Network-Based Approach for Emerging Rural Social Entrepreneurship
}

\author{
Seyedali Ahrari ${ }^{1}$, Steven Eric Krauss ${ }^{1}$, Zaifu Ariffin², Lee Kwan \\ Meng ${ }^{2}$ \\ ${ }^{1}$ Faculty of Educational Studies, Universiti Putra Malaysia, Serdang, Malaysia \\ ${ }^{2}$ Institute for Social Science Studies, Universiti Putra Malaysia, Serdang, Malaysia
}

\begin{abstract}
Rural social entrepreneurship (RSE) is one of the foundations of rural socio-economic development. However, RSEs have only recently been defined and few major research studies have been conducted. This paper reviewed current research on RSE employs the theoretical constructs of network approach and uses them to the study of RSE. These constructs as RSEs' function, relating to the structure of networks, social innovation, social learning and social value creation, are found by researchers to have importance in affecting strategy and measuring performance for social enterprise networks in rural areas. At the end, we come up with implications of how using network approach can strengthen the RSEs to develop competitive opportunities for rural areas by RSEs.
\end{abstract}

Keywords

Rural Social Entrepreneurship, Network Approach, Embeddedness, Social Innovation, Network Approach, Rural Development

\section{Introduction}

Entrepreneurship has a key role to play in rural development. This includes not only conventional entrepreneurial actions, although social entrepreneurship (SE) activities which unite social and economic aim. Nowadays, there are growing interests in SE in rural area for addressing complex sustainable development challenges such as environmental issues, food waste, and low energy efficiency. For regenerating rural area, there is a move away from national controlled socio-economic plans regarding delivery through organizations involving networks of public, private, and voluntary segment parties (Shucksmith, 2010). However, only recently the importance of RSEs in contributing toward socio-economic development has been recognized (Schultz, 2009).

Developing the rural community is one of the key indicators towards a nations' success. Proof from the Global Entrepreneurship Monitor (GEM) reveals that development in GDP and the occupation rate of a country rise with more venture startups (Zacharakis, Meyer, \& DeCastro, 1999). The complexity of socio-economic challenges calls for new ways such as RSE to address various issues such as poverty, income inequality, social exclusion, unemployment, outmigration, deteriorating living conditions which are more acute in rural areas (Shedenova \& Beimisheva, 2013). However, 
INTERNATIONAL JOURNAL OF ACADEMIC RESEARCH IN BUSINESS AND SOCIAL SCIENCES Vol. 8, No. 9, Sept. 2018, E-ISSN: 2222-6990 @ 2018 HRMARS

potential of rural area such as food security and rural tourism is not used for development of nations (Greblikaite et al., 2017).

Rural people are particularly underprivileged groups and face difficulties result from socio-economic and technological environs that impede their living conditions (Amine \& Staub, 2009). RSEs have the ability to draw in solutions by businesses to solve social problems to become more resilient. RSEs can identify and solve social problems on a large scale and assist in social transformation of the economy. Studies have shown that SEs have become a global phenomenon, which affects society through pioneering approaches especially in rural areas by creating socio-economic opportunities (e.g., Robinson \& Stubberud, 2009). In this regard, the embeddedness of SE in rural societies and their capability to interact with rural societies is vital preconditions for generating social innovation (Richter, 2017). This is reinforced by considerable signs that most activities of RSEs are focused on proposing support to underprivileged rural areas and SE is the only option for employment and engagement (Parker, 2018). By developing existing RSEs, social entrepreneurs have the chance to help communities and to be a catalyst for social change throughout their community.

Despite growing interest in RSEs for the purpose of rural development, there is no clear theoretical approach to study the challenges faced by RSEs in some contexts (Zhu et al., 2015). Studies on RSEs have only currently started to adopt a network-based approach and its impact on their respective activities and performance and thereby limited studies have been conducted exists for a theory of network development (e.g., Hoang \& Antoncic, 2003; Mair \& Marti, 2006). Rural area is also a perfect nurturing ground for SE because of the existence of unique network features (e.g., identifying opportunities, mobilizing resources) are associated with being part of a rural community. Previous research revealed the need of deeper research of SE challenges in rural areas from a network-based approach because of lack of concrete research (Jack \& Anderson, 2002). This study is intended to study repetitions from previous studies on reinforcing rural community growth by SE. The focused is simply to assist to determine RSE matters that could enhance socio-economic development of rural community. Finally, the network-based approach provides a novel model for recognizing the initiation and diffusion of RSEs, and it builds noticeable the use of network links for the trade of information and the gaining of resources, for the embeddedness in rural communities and for the interrelation amid rural communities and social enterprise networks.

\section{Literature Review}

\section{Rural Social Entrepreneurship}

As the phenomenon of RSE is new, most research has focused on social enterprises in urban contexts. Rural areas share a set of challenges and there is increasing interests in the delivery of opportunities by non-governmental players (McCarthy, 2012). Also, the question of vitalizing rural zones through the support of SE has produced substantial interest (Petrov, 2008). Social enterprise started to be enacted in the 1980s, though its theoretical discussion has strengthened in the last 20 years (Defourny \& Nyssens, 2010). More market driven than conventional not-for-profit ventures, and with the ability to be fiscally self- supporting, the expression "social enterprise" has been invented by government and other interested parties to signify socially driven sectors (Di Domenico, Haugh, \& Tracey, 2010). Main social enterprise actions comprise; trading, service delivery bonds, cross-sector collaborations, cultural virtuosities, social growth, learning, and work skills training, care facility; community care arrangements; cheap transportation; recycling, and substructure and subsidized accommodation (Pearce \& Kay, 2003). 
INTERNATIONAL JOURNAL OF ACADEMIC RESEARCH IN BUSINESS AND SOCIAL SCIENCES

Vol. 8, No. 9, Sept. 2018, E-ISSN: 2222-6990 @ 2018 HRMARS

Since the 1990s, RSEs have been recognized as prospective developers of pioneering ways of confronting social glitches (Shaw, 2004). They can help rural communities to respond to challenges and become stronger. While some RSEs address the needs caused by socio-economic and political changes (e.g., withdraw of some public/private sectors), other are more proactive utilize available resources to enhance rural development (Plunkett Foundation, 2016). Considerable resources have been devoted to encourage SEs to help rural people achieve financial sustainability and social wellbeing (Nicholls \& Teasdale, 2017).

Rural areas allow the employment of a place for concentrated activities and links to social living (Korsgaard, Müller, \& Tanvig, 2015). Certain SEs transfer to rural zones because of their benefits in terms of small city living and firmer social bonds. It indicates RSEs are attracted in how they are part of the social embeddedness of an area and presently inhabit a niche place in rural societies (Fortunato, 2014). For SEs, this allows new arrangements and combinations of resources that can improve the socio-economic situations of rural area (Ratten, 2018). It might be considered that rural regions signify an ideal cultivating base for SE because of the existence of reciprocity, collective activity and those aspects which are associated with being part of a rural community. It could be surmised that RSEs might build on this extant solidarity.

According to Steiner and Atterton (2015), SE has three hybrid characteristics which are important values for rural people including enterprise orientation, environmental aims and societal ownership which make rural areas suitable for rural community development. The SEs offer all-inclusive approach to tackling social problems in rural communities. Warren (2004) found that rural financial system needs restructuring, which existing agronomic rules lonely (e.g., current EU's Common Agricultural Policy) cannot guarantee. Steinerowski and Steinerowska-Streb (2012), for instance, discovered that SE can improve the capability of rural people to adapt to basic challenges while their aptitude to perform as change agents is restrained. Previous literature examine RSE as a cooperative rather than as the initiatives of individual entrepreneurs (e.g., Munoz, Steiner, \& Farmer, 2014). Though, the studies propose that the drive behind and the recognition of RSEs differs between nations because of some main background features, particularly related to historical direction, financial growth stage and personal practices. While RSEs in Sweden arise from native schemes and find extensive recognition (Friedrichs \& Lundström, 2017), in the UK the search for SE initiatives seems to be more governmental driven and meets confrontation from rural people. RSEs also in China have shifted from traditional social-work orientation to the balance of economic success and social goals after socio-political reforms (Lan et al., 2014).

There is dispute over SE essence to address small markets for products and services in remote rural regions; however the their main goal must be enacting real changes in lives of people (Cieslik, 2016). These transformations can be establishing connecting networks to allow rural people to access to critical matching assets (e.g. administrative validity and acceptability, consultancy, public funding, venture capital) and therefore help maximize place-based communal resources (Kilpatrick et al., 2015). There are also some differences between rural and urban social entrepreneurship (Smallbone \& Welter, 2001). Though, it would seem that social enterprises are quite established in rural regions than urban regions, however their contribution to rural development isn't fully recognized (Steiner \& Teasdale, 2017). The kind of social ties varies when comparing urban and rural settings. Rural social ties play an important role because many people know each other. In urban areas social ties matter as well - but rather differently. People only know a limited set of other persons and are often rather selective in building relationships. As social networks are a vital part of founding businesses, this 
INTERNATIONAL JOURNAL OF ACADEMIC RESEARCH IN BUSINESS AND SOCIAL SCIENCES Vol. 8, No. 9, Sept. 2018, E-ISSN: 2222-6990 @ 2018 HRMARS

peculiarity may also be relevant to differ among these two kinds of social entrepreneurship (Mayer, Harima, \& Freiling, 2015). The UK's Countryside Agency (2003) discovered that, comparing urban SEs, RSEs have a tendency to be more concentrated on public transport, farming organizations, public centres, and environmental actions. The societal tenure of social enterprises also makes commercial occasions in rural areas (Sodhi \& Tang, 2011). The ability of RSEs to reach their goal relies on devoted people and their communal actions (Pickernell et al., 2007). Thus, there are a few enthusiastic individuals in rural area to be act as social entrepreneur (Munoz et al., 2014).

\section{Challenges Of Rural Social Entrepreneurships}

RSEs as change agents face various constraints due to challenging situation in rural areas that can be a deprived of resources (A. Steinerowski, Jack, \& Farmer, 2008). Thus, an investigation of the possible barriers to RSEs is vital. Generally, the social norms in the rural areas are significantly traditional and many conventional rules place restraints on innovative thoughts and activities. The mainstreams of rural people are adapted to the traditional lifestyle and challenging the present systems is a tough task for fostering innovations (Kibler, Kautonen, \& Fink, 2014).

One of the main challenges of RSEs is competing social and commercial aims. It is difficult to get right as it is essential to compare between profitable feasibility and aiming social issues. This challenge is more obvious in rural areas because of lack of customers and low income profits. Majority of RSEs are not completely concentrate on economic objectives and the process of decisions over their business models are very time-consuming and not efficient. This creates obstacles for RSEs to become viable social businesses. Social enterprises can't be totally economic as they can't make only commercial choices. Most RSEs are not likely to forever be sustainable merely from trading products and amenities (Steinerowski \& Steinerowska-Streb, 2012). In part this might be attributable to a conventional hostility towards more business-focused tactics, mainly among the more voluntary sectors where there is often resistance to risk and sustaining RSEs is therefore complex (Whitelaw, 2012). Despite close ties, there is lack of supportive culture of change in rural area (Kayne, 2013) Previous research over RSEs revealed how the official context - both in its administrational and social planning - can make huge obstacles to encourage innovations (Kibler et al., 2014). Many RSEs may need an entrepreneurial tactic for innovations. While diverse stages of risk might be suitable in different stages of activities, fearing to make risk by RSEs, put them in a situation to serve only economic objectives or fail to address social needs (Muñoz \& Steinerowski, 2012).

In the establishment of RSEs is challenging and needs the social entrepreneurs to be skilled and qualified in strategic thinking, to be determined with objectives, adaptable to handle changes, and to lead skills. Previous research showed that the main consideration was to improve social welfare by learning sustainable agronomics, preserving traditional cultures, and attaining shared affluence by RSEs (Lan et al., 2014). However, rural communities experience limited opportunities for wider social learning (Farmer et al., 2011). According to BenYishay and Mobarak (2014), rural people appear to be most convinced by the advice of others who face local conditions. The social networks that were usually created through a common identity can't provide the resources for binding people.

Moreover, information is expected to be the most effective rural growth tool. Rural areas as Ramalingam et al., (2008) stated lack in exchange information results in conserving old structures resisting new ideas and markets. This leads to lack of social issue awareness and results in frustrating attempts of RSEs who are attracted in the occasions to involve in social activities and adopting novel approaches (Razavi et al.,2014). Many rural people also do not have economic information and it is very risky for them to put their own assets for developing new business. Hence, the restructuring 
INTERNATIONAL JOURNAL OF ACADEMIC RESEARCH IN BUSINESS AND SOCIAL SCIENCES Vol. 8, No. 9, Sept. 2018, E-ISSN: 2222-6990 @ 2018 HRMARS

manner in rural zones has been seen as additive process (Lan et al., 2014). Mazzei and Roy (2017) also specified that supportive networks are not simply available for RSEs and it is demanding to exchange info with 'the right people'.

Most social entrepreneurs still depend on price-based valuing. The fundamental basis for price-based valuing being common is that the basic value to society is an abstract feature compared to price and product ingredients (Mendoza-Abarca \& Mellema, 2016). Those operating social enterprises emphasized that revenue creation in rural zones is problematic. It is, therefore, rather difficult for most consumers to recognize the hidden social value in the product. Another reason may be the type of social enterprise products being consuming commodities (e.g. agricultural products) which might prevent the RSEs from marking up the price based on the differentiated product value (Srivetbodee, Igel, \& Kraisornsuthasinee, 2017). Thus, many RSEs can't create social value from their selling tactic because of not paying particular consideration to the revenue of producers and the problem in the society. Srivetbodee, et al., (2017) found that many social entrepreneurs didn't propose customers products that address specific social challenges, such as neediness or unemployment and couldn't create social values in their targeting rural community.

\section{The Current Study}

As the hypothetical field of SE has changed and developed, it has profited from the introduction of ideas originated from a wide range of academic traditions and practices. The purpose of this study is to comprehend the position of RSEs from the network-based approach. We notice from past studies how networks and embeddedness (Cope, Jack, \& Rose, 2007; Jack \& Anderson, 2002; Jack, Moult, Anderson, \& Dodd, 2010) have challenged the notion of the isolated entrepreneur (Drakopoulou Dodd \& Anderson, 2007). The existing literature was not sufficient in raising awareness of the different issues among RSEs. Numerous plans were introduced by the nations to reach the targets of socio-economic development and alleviation problems to the world of SE (Sarif, Ismail, \& Sarwar, 2012). Thus, understanding challenges of RSEs is vital to ensure that they can get the best possible experience in their communities. Previous studies on RSEs found several benefits and outcomes (Karanda \& Toledano, 2012). Nevertheless, little is known about RSEs. This draws attention to a gap in the RSE research. Previous studies suggest that rural communities are places with supposedly high levels of social networks and traditions of collective actions which make them the ideal context for social enterprise (e.g., Munoz, Steiner, \& Farmer, 2014).

RSEs seem to be driven by their place and networks or fostered by individuals, but seldom as selfdetermining means functioning in a planned way. Literature at the interface between RSEs as place based activity and network research is extremely scarce (Murdock \& Bradburn, 2005). Short et al. (2009) also point to the lack of theoretical research and call for further conceptual research. While the majority of entrepreneurs work under circumstances of resource scarcity, social entrepreneurs face a specific set of challenges because they purposely locate their activities in areas where markets function poorly. Di Domenico et al., (2010) highlighted that study of networks can be a way for social entrepreneurs accumulate resources in resource-poor settings. This includes any research in the field of RSEs, which focuses on the interrelation between networks of SEs and rural people. One consequence is a lack of knowledge about how RSEs develop innovative solutions. However, the concept of SE has been criticized as ill-defined, with more recent literature addressing these concerns (Short et al., 2009). Thus, this study aims at revealing the role of RSEs for sustainable rural development through analysis of the networks to its application. We seek to reveal how RSEs generate the innovative solutions, social learning, and social values in enabling rural communities to 
INTERNATIONAL JOURNAL OF ACADEMIC RESEARCH IN BUSINESS AND SOCIAL SCIENCES Vol. 8, No. 9, Sept. 2018, E-ISSN: 2222-6990 @ 2018 HRMARS

address challenges. The individual level in addition to the act and procedure viewpoints is intensely linked as RSE is the process through which social entrepreneurs develop social enterprises (Defourny \& Nyssens, 2008). Though, we concentrate chiefly on the social entrepreneur because our study takes the network-based approach with individual-level network relationships as its main feature.

\section{Application of network approach in rural social entrepreneurship The Network Approach Background}

The concept of the network approach emerges at the social studies, but its uniqueness in terms of theory becomes clear in the sociological works of the mid-twentieth century within the paradigm of structural functionalism (Milroy, 2000). Some scholars, like Huckfeldt and Sprague (1995), have long put network approach at the center of their study. For several researchers, "network approach" has been a 'bottom-up' way in terms of producing descriptions for social phenomena based on the significance of relationships with interacting units and the larger social system as networks are the very basis of all social interactions (Putnam, 2000). In conventional policies, socio-economic development has been a 'top-down' process (Lee, 2014). However, the relationships themselves (e.g., interaction, observation of each other's behavior, and interpretation of associations) have become the unit of analysis. This emphasizes the interconnectedness amid statuses, the actors, and how these associates mostly control access to resources embedded in a community or group of people. It can provide response to an inquiry that has preoccupied social sciences; namely, the problem of how separate individuals can be joined to make stable societies.

\section{Network Approach}

According to Borgatti and Foster (2003), a network is a group of actors linked to array of ties. It means some social structures link to particular cultural structures so that stabilities between social relationships and their effects on social constructions can be created. It shows that how people interact inside their network. A network consists of 'ties' the range of relationships connecting actors that connect the actors in the community (Wasserman \& Faust, 1994). On the personal level, it has previously been revealed that persons connecting structural holes are more productive (Burt, 2017). Gulati (1995) discovered that commercial contacts frequently grew from prior friendship ties. McPherson, Smith-Lovin and Cook (2001) also studied the network-based approach and its effects. They claim that people's personal networks are similar with reference to numerous sociodemographic, communicative, and intrapersonal features. It delivers a specific and precise way of mapping these kinds of informal flows, making the once hidden set of associations observable (Cross et al., 2003).

The network-based approach originated from structurationalism which emphasizes on interindividuals interactions (Jack \& Anderson, 2002). For applying the network-based approach for RSE field, Dershem et al. (2011) noted that with better connected of people through networks, nongovernmental organizations can make better results in a productive manner. With deeper relationships through networks of individuals, knowledge and info can spread faster which lead to cooperation. It would be make chances to produce new interactions and contacts. The network embeddedness allows for accessing for new assets for who are involved. While not strong and informal ties develop new information; dense ties help transferring difficult-to-exchange and professional information (Hansen, 2002). In contrast to weak ties, the strong ties are direct and formal in nature. However, the weak ties make an extensive structure of network/networks by structural holes to allow people at the interface to bridge these holes and gain different types of benefits (Burt, 2017). Hence, for gaining 
INTERNATIONAL JOURNAL OF ACADEMIC RESEARCH IN BUSINESS AND SOCIAL SCIENCES Vol. 8, No. 9, Sept. 2018, E-ISSN: 2222-6990 @ 2018 HRMARS

better results a large diversity of weak ties with a small portion of dense ties is needed and it requires energy, time, and care due to lack of resources (Burt, 2000).

For analytical purpose it is essential to separate two kinds of networks, the horizontal and the vertical networks (Malmberg, 2004). Putnam (2000) sorts social networks into 'vertical' hierarchical relationships and 'horizontal' unrestricted associations. Horizontal networks (interpersonal networks) are relationships between individuals in a society with similar positions. Horizontal linkages often serve to exchange information, knowledge and experience in community groups; to exchange products/clients, as in the case; and to complement and/or substitute skills/resources. Vertical networks (intra-personal networks) are more complicated assemblies, generally involved with the authority, and have official bound by regulations (Rose, 2000). Previous studies showed that social entrepreneurs who put more energy and time to expand their social networks have more sustainable business position (Rush et al, 1987), although Filion (1990) found that networking should also be deliberated as part of an extensive process which comprises the 'know-how' of entrepreneurs and their ideal and aim (Harrison \& Leitch, 2005). Networks may increase the possibility of success in numerous ways at different levels of the development of the business (McQuaid, 1996).

\section{Rural Social Entrepreneurship: A Horizontal Network Approach}

Until now, there are not many inquiries to study RSEs issues over complicated interplay of various types of networks for reaching their social goals. So far, networks of RSEs and rural people have rarely been discussed on the horizontal level. Because of over dependence of RSEs on external resources, previous studies concentrated on vertical networks (Lang \& Fink, 2018). It is necessary to consider interplay of the RSEs and rural people to understand societal dimension of RSEs for rural community development. The social dimension of RSEs wholly rely on the interaction between individuals and their networks (Johannisson, 2000). This intensified the role of RSEs' network ties over traditional entrepreneurships due to necessity to influence the venture's volunteers, to engage employees in their mission and make the internal attachment and pledge among them (Murdock \& Bradburn, 2005). Johannisson (1986) stated that personal networks are a major advantage to the potential social entrepreneur to develop the individual character which the entrepreneur is attempting to entail in his business.

Despite rural unfavorable places, their social networks may be possibly tapped for rural development through social entrepreneurial quests (Poon, Thai, \& Naybor, 2012). Though remote places make obstacles for many socio-economic actions (Pateman, 2011), social interconnection coming from a past commitment to self-help born from necessity has led to high levels of trust and active participation within rural communities (Skerratt, 2013). Rural socio-economic challenges might also offer opportunities. Rural communities are characterized by powerful networks, embeddedness and social activities in addition to having robust shared knowledge, sense of social cohesion (Woods, 2009). Thus, horizontal linkages exist between RSEs and rural people and experimental evidence demonstrates that local needs that are addressed by RSEs are primarily possessed by a group of community members (Fink, Lang, \& Richter, 2017).

Vertical networks as bridging social entrepreneurs to external resources such as governments are also important for RSEs (Lehner, 2011); however due to slow change and irresponsibility, it puts horizontal networks forward for a successful social development mission. Kibler et al., (2015) stated that the concept of RSEs is inherently linked to place, because such a venture's activities are anchored in a particular locality. Furthermore, RSEs explicitly mobilize place-based resources (e.g. collective 
INTERNATIONAL JOURNAL OF ACADEMIC RESEARCH IN BUSINESS AND SOCIAL SCIENCES Vol. 8, No. 9, Sept. 2018, E-ISSN: 2222-6990 @ 2018 HRMARS

identities, solidarity norms) for their operations so as to overcome institutional constraints (Welter \& Smallbone, 2011). Furthermore, the actual innovativeness of RSEs depends on the entrepreneur's ability to strategically recombine and leverage place-based resources in the business activity and local actors through horizontal networks (McKeever, Anderson, \& Jack, 2014). According to Kibler et al. (2015), RSEs can get advantage of place which represents horizontal networks or taking advantage of local resources (e.g. local amenities) as they are critical to entrepreneurial venturing.

The place is a significant basis for horizontal networks to function due to below details. First, social settings, like farm communities or rural councils, serve as imperative networks of enrollment and involvement, directing rural persons into collective action, friendship ties, and the social prospects that are formed during interaction (Mark \& Harris, 2012). Second, they involve rural people in interactions that potentially expose them to a variety of perspectives and ideas than they would otherwise find among clan, acquaintances, and neighbors (Huckfeldt \& Sprague, 1995). For instance, Fischer (2000) found that rural people are more likely to know each other, thereby resulting in greater opportunities for volunteerism. Third, the flexibility of certain settings can affect the interaction results (Van der Gaag \& Snijders, 2004). Finally, the embeddedness in rural setting is possibly to be pivotal in deciding whether the venture is supported or boycotted by local people (Keeley \& Roure, 1990). It shows that the effectiveness of the RSEs' activities also relies on the people's willingness (Thuesen \& Rasmussen, 2015). Thus, by directing business model on place-based gains, RSEs become appealing for rural people who are driven by the idea to contribute their resources to have a positive impact on rural community development, for example by job creation or reinforcing social cohesion.

\section{Social Dimensions of RSE through Horizontal Networks}

SE is seen as organizations which build on strong ties among their members (Hatak, Lang, \& Roessl, 2016). They make important improvements in the way things are done in the social sector. And yet they may act domestically, their actions have the ability to accelerate global improvements in their selected grounds, whether that is education, economic development, and environment, (Schumpeter, 1954). A review of literature showed that horizontal networks have direct impact on individuals' output, namely: attitude similarity, performance, getting ahead, revenue, (Rao, Davis, \& Ward, 2000). Capello (1996) showed that the network-based approach offered the suitable tools through which to facilitate social learning, innovation and value-creation in rural area. The horizontal networks seek to establish a 'third way' to foster social innovation and learning (OECD, 1996). Dees, Emerson, and Economy (2004) also redefined SEs as innovative and instructive practices for the purpose of social change. As the major drivers of rural social development, RSEs have some capabilities as indicated by Huang and Cui (2009), such as self-learning and obtaining knowledge, applying knowledge to practice, and innovation. The horizontal networks seek to overcome innate resource limitations of individual RSEs through the exchange of knowledge in order to increase innovation and collaborative product development (Lamprinopoulou \& Tregear, 2011). Over and above the positive externalities of RSEs, such as social innovation, social learning, and social value creation of rural social entrepreneurs address societal challenges such as unemployment, poverty, social exclusion and marginalization (Lang \& Fink, 2018). The horizontal networks have key functions that may permit RSEs to serve as dynamic building blocks for the rural community development.

\section{Social Innovation}

In contrast of Innovation which is defined as a new method and application of

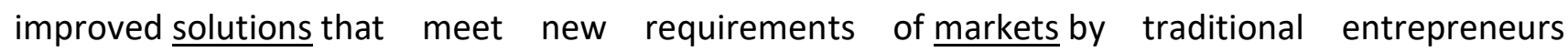


INTERNATIONAL JOURNAL OF ACADEMIC RESEARCH IN BUSINESS AND SOCIAL SCIENCES

Vol. 8, No. 9, Sept. 2018, E-ISSN: 2222-6990 @ 2018 HRMARS

(Maranville, 1992), social innovation (SI) refers to activities those are motivated by the goal of meeting social needs and those are diffused through RSE activities such as employment, consumption, participation, and production (Caulier-Grice et al., 2012). SI is important to address rural social problems and seen as a pillar in bottom-up developmental tactic to overcome social challenges (Nordregio, 2016). There is a lack of SI which restrains the development of rural areas due to a shortage of facilitators for ideas, participators in policies, and supporters of embracing change (Richter, 2017).

RSEs can undertake SI in an effort to tackle social problems through rural needs (Lang \& Fink, 2018). RSEs can develop SIs that are viable to private sectors and compensate blocks that are experienced by governments in the provision of local services and allows for creating $\mathrm{SI}$ in areas such as education, the environment and business development (Dobele, Grinberga-Zalite, \& Kelle, 2015). Abdulmelike (2017) showed that absence of RSEs causing lack in SI. RSEs are more likely to convince people to adopt innovative ideas by recognition and trust because RSEs are typically well embedded in local communities (Seelos et al., 2011). SI is the outcome of a recombination of current elements, grasping new ideas makes it possible to grow new combinations with the ability to resolve social issues (Esparcia, 2014). Thus, RSEs can function as mediators between remote places, individuals, and groups (Christmann, 2014). The business activity of RSEs contributes innovative ways to meet the needs of local rural communities. Steiner and Atterton (2015), found rural people relational capacity and the culture of trust are promising conditions for the identification of social needs and the development of SI.

The horizontal network approach has a promising tool for the analysis of SI by RSE researchers for three reasons (Austin, Stevenson, \& Wei-Skillern, 2006). First, networks are intangible substructures for transferring ideas, which are requirements for SI. Second, rural social networks are requirements for the embeddedness of RSEs and the opportunity to diffuse SI. Third, it can reveal how social interactions through horizontal networks can provide impetus for the development of SI by improving the efficacy of society by facilitating coordinated actions. Ray (1998) showed that the EU's experience in redirecting funds way from horizontal and towards vertical networks was not successful in generating $\mathrm{SI}$ in rural areas because local actors are the best choice for recognizing problems and dealing with activities are necessary to tackle them. Strong networked relations of rural people and RSEs make for flexibility in adapting to changes in the non-agricultural aspects to remain within the local economy and reduce over dependence on vertical networks (Grootaert \& Van Bastelaer, 2002). Dense rural networks of RSEs show the social embeddedness of the enterprise, which is vital for recognizing social needs and for promoting SI. Hence, Steiner and Atterton (2015) comprehend local embeddedness as the overlap of social and financial relationships and networks in a precise geographic area. The local embeddedness of entrepreneurial action is mainly significant for rural social entrepreneurs who direct their efforts to solving social challenges in rural communities. For instance in Weissensee district in Austria, RSEs invented a developmental bottom-up concept 'playground for nature' for local people. One outcome was the overview of communal possessions payments for the naturally sound cultivation of agricultural areas and abandon of pesticides and chemical fertilizers in favor of grassland farming and attract nature tourists (Pollerman, 2014).

\section{Social Learning}

Social learning (SL) is a long-term process of learning from interaction and modify own behavior and seen as a powerful ingredient of change (Röling \& Jiggins, 2001). It is a strategy for working with rural people who have will to change (Rodríguez \& Vergara-Tenorio, 2007) which implies an emphasis on 
INTERNATIONAL JOURNAL OF ACADEMIC RESEARCH IN BUSINESS AND SOCIAL SCIENCES Vol. 8, No. 9, Sept. 2018, E-ISSN: 2222-6990 @ 2018 HRMARS

the process of how rural people and RSEs are able to learn and transmit knowledge via interaction to develop their ability to expose new experiences of resource management, take their own future directions with benefits for their individual self-esteem and rural sustainable development (Rodríguez \& Vergara-Tenorio, 2007). Rural communities are important in facilitating information exchange amongst members due to fundamental attachments to a place which enable intimate ties and a sense of community with shared experiences (Barrett \& Weinstein, 2015). According to Vaarst (2007) the formation of rural community facilitates SL as a cyclic process.

Networks play an essential role in reflecting SL (Wenger, 2010). The process of SL includes learning new knowledge and existing experiences, transforming it through practical learning, and using it among a network of individuals who share common senses (Wenger, 2010). These networks are the social infrastructure that support SL (Phelps, Heidl, \& Wadhwa, 2012). A successful SL process depends on the structure of the network and the individual's position in that network. The horizontal networks can act as a local resource donation and public platform of knowledge exchange in rural areas (Novy, Swiatek, \& Moulaert, 2012). SL is communication processes between similar actors, actor networks and other means of co-operation, that are new in relation to the horizon of experiences of the people which is an important factor for the success of bottom-up regional development (Neumeier, 2012). Therefore, interactions are important to fully understand local knowledge and facilitate the SL process (Agrawal \& Gibson, 2001).

RSEs engaging in a process of SL when they create their networks and create opportunities for knowledge sharing (Karanda \& Toledano, 2012). By SL, RSEs build their competence to face the challenges, in particular related to knowledge of new products, technology and markets by more voluntary support from rural people would enhance their capability. This also helps rural people to learn social skills and inspires them to acquire the self-confidence, and use new solutions needed to tackle social problems (Dees, 1998). Sometimes, RSEs may be responsive to new economic opportunities. It is increasingly accepted that RSEs can present alternatives to the work organizations, the transfer of knowledge and new perspective to the market (White \& Kenyon, 2001).

SL can help rural people to grow sympathetic of structures such as fiscal risk and the importance of mobilization of resources in making real profits even with limited learning opportunities due to limited resources (Pittaway et al., 2011). As an example, in X'pujil Mayan community, Mexico, RSEs created a micro-project by eight rural participants in 1992. The group have been successful in reproducing small cattle, forage and wood tree management, as well as enrichment of secondary forest and their experiences learned and repeated by nearby rural parcels (Amo Rodríguez \& Rorive, 2004).

\section{Social Value Creation}

Value is a notion of worth which is related to the use of a product or service and recognized by clients before quantitatively ascertained (Dumond, 2000). Social value (SV) is described as something of value for society in the selected areas (Dietz \& Porter, 2012). Kroeger and Weber (2014), define SV as positive change, initiated by a social intervention in the subjective well-being of disadvantaged individuals. SV creation can be defined as generating employment opportunities, work integration, skills development, training and development, social capital, and community cohesion (Di Domenico et al., 2010). The reconceptualization of SV creation as a leveraging business to solve social problems and can be used as an analytical framework for success of SEs (Sinkovics, Sinkovics, \& Yamin, 2014). It has been linked to approaches gauging social impact within RSEs and it is as feature of RSEs (Dayson, 
2013). This feature has not been considered in earlier expositions of traditional enterprises (Baker \& Nelson, 2005).

SE is often defined as the practice of solving social issues through the development of entrepreneurial social ventures which create economic and social value to address social needs (Dacin, Dacin, \& Matear, 2010). In traditional entrepreneurship, the revenue a company produces can be employed as a rational indicator for the value it produces (Dees, 1998). Wealth creation is a mutual goal for conventional entrepreneurship and is naturally measured by financial returns (Austin et al., 2006), the social business context is different from this norm; prosperity creation is just a mean to an end for SEs (Dees, 1998). A social entrepreneur involves in entrepreneurial activities that is categorized by a social aim and creates SV. The primary social goal is what separates social from traditional entrepreneurship (Austin et al., 2006). The social aim rises from the objective to focus on investor value instead of wealth expansion (Zahra et al., 2009). RSEs search for the most efficient methods to serve their social mission, which does not prevent the common creation of economic and social value (Dees, 1998). A widespread opinion within the SE literature is that it accords a higher priority to SV than to obtaining economic value (Mair \& Marti, 2006). However, Lautermann's (2013) suggested reconceptualization of SV creation as entrepreneurial value, while logically interesting, does not achieve the aim of penetrating the core of SV creation. More accurately, it approaches Acs et al.'s (2013) proposal about the inseparability of the social and financial value of dynamic entrepreneurship.

Normann and Ramirez (1993) showed that the importance of horizontal networks via interaction on creating SV by RSEs which their embeddedness in specific configuration becomes pivotal. During RSEs activities in rural area, horizontal networks are responsible for creating SV between individuals (Korsgaard \& Anderson, 2011). In this regard, Young (2008) showed that RSEs influenced positively SV creation resulting from engagement in social enterprises. The drive of social businesses is to address public interests, which are related to SV. Even with traditional entrepreneur's purpose of maximizing profit and create economic value, the possibility of creating SV is increasing with their social responsibilities (Hlady-Rispal \& Servantie, 2018). RSEs use entrepreneurial tools linked to profitable entrepreneurship to attain SV creation (Kickul \& Lyons, 2012). The public and interested parties are vital for SEs to help determine both the SV of the enterprises and how to resolve social problems (Kickul \& Lyons, 2012). 
INTERNATIONAL JOURNAL OF ACADEMIC RESEARCH IN BUSINESS AND SOCIAL SCIENCES Vol. 8, No. 9, Sept. 2018, E-ISSN: 2222-6990 @ 2018 HRMARS

\begin{tabular}{|c|c|c|}
\hline & Rural Community & \\
\hline RSES & \multirow{6}{*}{$\overbrace{}^{\text {Horizontal Networks }}$} & Rural People \\
\hline Challenges & & Challenges \\
\hline Traditional norms & & Poverty \\
\hline $\begin{array}{c}\text { Competing social \& fiscal } \\
\text { aims }\end{array}$ & & Lack of infrastructure \\
\hline $\begin{array}{l}\text { Limited learning } \\
\text { opportunities }\end{array}$ & & Unemployment \\
\hline \multirow[t]{2}{*}{ Cost based pricing } & & Closed community \\
\hline & $\begin{array}{l}\text { Individa } \text { output } \\
\text { Social innovation } \\
\text { Social learning } \\
\text { Social value creation }\end{array}$ & \\
\hline
\end{tabular}

Figure 1. Horizontal network in rural community

\section{Conclusion}

A network approach has key functions that may permit RSEs to serve as dynamic building blocks for the rural community development. The present study considered horizontal network in rural community to understand societal dimension of RSEs for rural community development, including social innovation, learning, and value creation. We introduced horizontal networks as new way to understand societal dimension of RSEs in addressing rural social needs. This approach provided a heuristic for understanding the generation and diffusion of social innovation in a rural setting. It focused on past studies and concentrated on a proper theory to analyze the empirical data. RSEs involvement in horizontal networks allows them to invent novel ideas, to learn knowledge and to create social values. This allows RSEs to endure through the process of restructuring and modification (Lang, Fink, \& Kibler, 2014). The interaction of rural social entrepreneurs and rural people (nodes) and their networking abilities as social structure reflects social networks that connect rural societies (Sharp, 2001). We found three main functions of RSEs to remedy social issues in rural places which before didn't address by ordinary entrepreneurial studies. Horizontal networks depend on equal status of both social entrepreneurs and rural people that are not top-down or business interactions (Hardy, Phillips, \& Lawrence, 2003). As mentioned, these types of networks occur as a reply to social needs and various problems of many countries especially in rural areas arises from vertical based strategies. Thus, it is become important for RSEs to deal with profit-based entrepreneurship and ways to ascertain social mission thru horizontal networks. All rural actors can establish links with networks horizontally and flows of information and goods inside and outside the local structure. Thus, horizontal based RSEs can help main supporters, investors, and policies to frame improved understandings of development in rural are based on their social needs. It also allows interaction with different levels of government and private firms to generate the necessary networks and funding networks. This enables identification and further systematic empirical study of how RSEs tactically reorganize different relations for their business model by leveraging community-level resources through horizontal linkages to rural level actors. We believe horizontal networks help to understand the complex role of RSEs as mediators for rural people for developing rural area. 
INTERNATIONAL JOURNAL OF ACADEMIC RESEARCH IN BUSINESS AND SOCIAL SCIENCES

Vol. 8, No. 9, Sept. 2018, E-ISSN: 2222-6990 @ 2018 HRMARS

\section{Implications}

\section{Theoretical Implications}

Academics might use addition specific case studies to dig deep into the exact meaning of specific horizontal networking repetitions of RSEs. Future studies should compare individual rural aspects and RSE performs thru different case studies for making generalizations. Forthcoming researches can advance horizontal network perspective over RSEs. These studies need to test horizontal network relationships empirically to make sure whether it holds true in other rural settings. Scholars must recognize the business models for individual setting for a better public support. Make interactions and deployment of resources needs actors to get acceptability in the rural community. It is a key challenge for the RSEs when choose and implement their business models. Thus, RSEs have to make a value plan for rural actors which in reality are often based on potential rather than actual resource access in his or her networks.

\section{Practical Implications}

Also, based on local knowledge of rural people, social entrepreneurs should adapt their business models on expertise of locals to tackle challenges Developing human resources may include building rural people's capacity to reach other rural social entrepreneurs outside of their immediate community region. As the importance of the work of RSEs in social problem alleviation continues to increase, the related researchers in the field should be instrumental in introducing social innovative ways that rural people are vital to socio-economic development, and influential in promoting the SL of local rural knowledge, crating SV by rural people.

Interpretation the character and influence of trigger restrictions is obviously significant, mainly for what type of abilities and policies may allow RSEs to realize their main abilities in rural areas. This is maybe the most vital query that future research requires to explore. Contextual investigations of trigger constraints and their impact on business would be of value to develop a deeper understanding of SI, SL, and SV creation in the context of horizontal networks. If there is a strong support network, then it is possible that this support may also be a driving force in providing the confidence for rural social entrepreneurs to build new ventures. In addition, forthcoming research may wish to further discover the concept of trigger restraints both theoretically and empirically. The association between binding restrictions and business model growth and adaptation is also an interesting area that needs to be explored further. As the nature of the current study is firmly experimental, future research will need to explore the ideas put forward in this paper in more details.

\section{Acknowledgment}

This research is funded by Universiti Putra Malaysia's Research Grant (GP-IPB/2016/9484000).

* Corresponding Author: Seyedali Ahrari; Email: seyedaliahrari@gmail.com

\section{References}

Abdulmelike, A. (2017). Social entrepreneurship: Literature review and current practice in Ethiopia. European Journal of Business and Management, 9(31), 86-93.

Acs, Z. J., Audretsch, D. B., \& Lehmann, E. E. (2013). The knowledge spillover theory of entrepreneurship. Small Business Economics, 41(4), 757-774.

Agrawal, A., \& Gibson, C. C. (2001). Communities and the environment: ethnicity, gender, and the state in community-based conservation. New Brunsick, Canada: Rutgers University Press. 
INTERNATIONAL JOURNAL OF ACADEMIC RESEARCH IN BUSINESS AND SOCIAL SCIENCES

Vol. 8, No. 9, Sept. 2018, E-ISSN: 2222-6990 @ 2018 HRMARS

Amine, L. S., \& Staub, K. M. (2009). Women entrepreneurs in sub-Saharan Africa: An institutional theory analysis from a social marketing point of view. Entrepreneurship and Regional Development, 21(2), 183-211.

Amo Rodríguez, S. del, \& Rorive, V. (2004). The Tropical Forest Action Program: A different way to handle the Management and Conservation of natural Resources. In A. Gómez-Pompa, M. F. Allen, S. L. Fedick, \& J. J. Jimenez-Osornio (Eds.), The Lowland Maya Area. New York, NY: New York Foods Products Press.

Austin, J., Stevenson, H., \& Wei-Skillern, J. (2006). Social and commercial entrepreneurship: same, different, or both? Entrepreneurship Theory and Practice, 30(1), 1-22.

Baker, T., \& Nelson, R. E. (2005). Creating something from nothing: Resource construction through entrepreneurial bricolage. Administrative Science Quarterly, 50(3), 329-366.

Barrett, H., \& Weinstein, A. (2015). Corporate entrepreneurship, the marketing mix, and business performance. In Proceedings of the 1997 Academy of Marketing Science (AMS) Annual Conference (pp. 144-150). Coral Gables, FL: Springer.

BenYishay, A., \& Mobarak, A. M. (2014). Social learning and communication (Working Paper No. 20139). National Bureau of Economic Research. Retrieved from http://www.nber.org/papers/w20139

Borgatti, S. P., \& Foster, P. C. (2003). The network paradigm in organizational research: A review and typology. Journal of Management, 29(6), 991-1013.

Burt, R. S. (2000). The network structure of social capital. Research in Organizational Behavior, 22, 345-423.

Burt, R. S. (2017). Structural holes versus network closure as social capital. In K. S. Cook, N. Lin, \& R. S. Burt (Eds.), Social capital (pp. 31-56). New York, NY: Routledge.

Capello, R. (1996). Industrial enterprises and economic space: the network paradigm. European Planning Studies, 4(4), 485-198.

Caulier-Grice, J., Davies, A., Patrick, R., \& Norman, W. (2012). Defining social innovation (A deliverable of the project:"The theoretical, empirical and policy foundations for building social innovation in Europe"(TEPSIE)). European Commission-7th Framework Programme, Brussels: European Commission, DG Research.

Christmann, G. B. (2014). Social entrepreneurs on the periphery: uncovering emerging pioneers of regional development. DisP-The Planning Review, 50(1), 43-55.

Cieslik, K. (2016). Moral economy meets social enterprise community-based green energy project in rural Burundi. World Development, 83, 12-26.

Cope, J., Jack, S. L., \& Rose, M. B. (2007). Social capital and entrepreneurship: An introduction. International Small Business Journal, 25(3), 213-219.

Countryside Agency. (2003). OPENspace: The research centre for inclusive access to outdoor environments (p. 92). Retrieved from https://www.gov.uk/government/organisations/countrysideagency

Dacin, P. A., Dacin, M. T., \& Matear, M. (2010). Social entrepreneurship: Why we don't need a new theory and how we move forward from here. Academy of Management Perspectives, 24(3), 37-57.

Dayson, C. (2013). Understanding the place based social value created by new-start social enterprises: evidence from ten rural UK communities. People, Place \& Policy Online, 7(1), 30-45.

Dees, J. G. (1998). Enterprising nonprofits. Harvard Business Review, 76(1), 54-69.

Dees, J. G., Emerson, J., \& Economy, P. (2004). Strategic tools for social entrepreneurs: Enhancing the performance of your enterprising nonprofit (Vol. 207). New York, NY: John Wiley \& Sons. 
INTERNATIONAL JOURNAL OF ACADEMIC RESEARCH IN BUSINESS AND SOCIAL SCIENCES

Vol. 8, No. 9, Sept. 2018, E-ISSN: 2222-6990 @ 2018 HRMARS

Defourny, J., \& Nyssens, M. (2008). Social enterprise in Europe: recent trends and developments. Social Enterprise Journal, 4(3), 202-228.

Defourny, J., \& Nyssens, M. (2010). Conceptions of social enterprise and social entrepreneurship in Europe and the United States: Convergences and divergences. Journal of Social Entrepreneurship, 1(1), 32-53.

Dershem, L., Dagargulia, T., Saganelidze, L., \& Roels, S. (2011). NGO Network Analysis Handbook: how to measure and map linkages between NGOs. Save the Children. Tbilisi, Georgia. NGO Network Analysis Handbook-Save the Children, 3, 3.

Di Domenico, M., Haugh, H., \& Tracey, P. (2010). Social bricolage: Theorizing social value creation in social enterprises. Entrepreneurship Theory and Practice, 34(4), 681-703.

Dietz, A. S., \& Porter, C. (2012). Making sense of social value creation: Three organizational case studies. Emergence: Complexity \& Organization, 14(3), 23-43.

Dobele, L., Grinberga-Zalite, G., \& Kelle, L. (2015). Sustaibanle economic development: Scenarios for promotion of social innovation in Latvia. Journal of Security \& Sustainability Issues, 5(2), 149-158.

Drakopoulou Dodd, S., \& Anderson, A. R. (2007). Mumpsimus and the mything of the individualistic entrepreneur. International Small Business Journal, 25(4), 341-360.

Dumond, E. J. (2000). Value management: an underlying framework. International Journal of Operations \& Production Management, 20(9), 1062-1077.

Esparcia, J. (2014). Innovation and networks in rural areas. An analysis from European innovative projects. Journal of Rural Studies, 34(1), 1-14.

Farmer, Jane, Muñoz, S.-A., Steinerowski, A., \& Bradley, S. (2011). Health, wellbeing and community involvement of older people in rural Scotland. Health and Wellbeing: A Social and Cultural Perspective, New York, NY: Nova Science Publishers, 127-42.

Filion, L. J. (1990). Entrepreneurial performance, networking, vision and relations. Journal of Small Business \& Entrepreneurship, 7(3), 3-13.

Fink, M., Lang, R., \& Richter, R. (2017). Social entrepreneurship in marginalised rural Europe: towards evidence-based policy for enhanced social innovation. Regions Magazine, 306(1), 6-10.

Fischer, O. A. (2000). Blowflies of the genera Calliphora, Lucilia and Protophormia (Diptera, Calliphoridae) in South-Moravian urban and rural areas with respect to Lucilia bufonivora Moniez, 1876. Acta Veterinaria Brno, 69(3), 225-231.

Fortunato, M. W.-P. (2014). Supporting rural entrepreneurship: a review of conceptual developments from research to practice. Community Development, 45(4), 387-408.

Friedrichs, Y. vo., \& Lundström, A. (2017). Social entrepreneurship as collaborative processes in rural Sweden. In I. L. Andersen, M. Gawell, \& R. Spear (Eds.), Social Entrepreneurship and Social Enterprises (pp. 158-177). London, New York: Routledge.

Greblikaite, J., Gerulaitiene, N., Ziukaite, Z., \& Garcia-Machado, J. J. (2017). Social Economy: the Potential and Challenges of Social Enterprises in Lithuania. European Integration Studies, (11), 53-64. Grootaert, C., \& Van Bastelaer, T. (2002). Understanding and measuring social capital. Washington, DC: The World Bank.

Gulati, R. (1995). Does familiarity breed trust? The implications of repeated ties for contractual choice in alliances. Academy of Management Journal, 38(1), 85-112.

Hansen, M. T. (2002). Knowledge networks: Explaining effective knowledge sharing in multiunit companies. Organization Science, 13(3), 232-248. 
INTERNATIONAL JOURNAL OF ACADEMIC RESEARCH IN BUSINESS AND SOCIAL SCIENCES Vol. 8, No. 9, Sept. 2018, E-ISSN: 2222-6990 @ 2018 HRMARS

Hardy, C., Phillips, N., \& Lawrence, T. B. (2003). Resources, knowledge and influence: The organizational effects of interorganizational collaboration. Journal of Management Studies, 40(2), 321-347.

Harrison, R. T., \& Leitch, C. M. (2005). Entrepreneurial learning: Researching the interface between learning and the entrepreneurial context. Entrepreneurship Theory and Practice, 29(4), 351-371.

Hatak, I., Lang, R., \& Roessl, D. (2016). Trust, social capital, and the coordination of relationships between the members of cooperatives: A comparison between member-focused cooperatives and third-party-focused cooperatives. Voluntas: International Journal of Voluntary and Nonprofit Organizations, 27(3), 1218-1241.

Hlady-Rispal, M., \& Servantie, V. (2018). Deconstructing the way in which value is created in the context of social entrepreneurship. International Journal of Management Reviews, 20(1), 62-80.

Hoang, H., \& Antoncic, B. (2003). Network-based research in entrepreneurship: A critical review. Journal of Business Venturing, 18(2), 165-187.

Huang, Z. J., \& Cui, P. (2009). Nongcun zhifu daitouren nengli jiegou ji xingcheng jizhi yanjiu [The research of rural leaders' capability structure and formation mechanism]. Human Agricultural Sciences, 8(1), 176-178.

Huckfeldt, R. R., \& Sprague, J. (1995). Citizens, politics and social communication: Information and influence in an election campaign. Cambridge: Cambridge University Press.

Jack, S. L., \& Anderson, A. R. (2002). The effects of embeddedness on the entrepreneurial process. Journal of Business Venturing, 17(5), 467-487.

Jack, S. L., Moult, S., Anderson, A. R., \& Dodd, S. (2010). An entrepreneurial network evolving: Patterns of change. International Small Business Journal, 28(4), 315-337.

Johannisson, B. (2000). Networking and entrepreneurial growth. In D. Sexton \& H. Landstrom (Eds.), Handbook of entrepreneurship (pp. 368-386). London: Blackwel.

Johannisson, Bengt. (1986). Network strategies: Management technology for entrepreneurship and change. International Small Business Journal, 5(1), 19-30.

Karanda, C., \& Toledano, N. (2012). Social entrepreneurship in South Africa: a different narrative for a different context. Social Enterprise Journal, 8(3), 201-215.

Kayne, L. (2013, August 5). Social enterprise in Indian slums. The Guardian. Retrieved from http://www.theguardian.com/sustainable-business/social-enterprise-india-slums

Keeley, R. H., \& Roure, J. B. (1990). Management, strategy, and industry structure as influences on the success of new firms: A structural model. Management Science, 36(10), 1256-1267.

Kibler, E., Fink, M., Lang, R., \& Muñoz, P. (2015). Place attachment and social legitimacy: Revisiting the sustainable entrepreneurship journey. Journal of Business Venturing Insights, 3, 24-29.

Kibler, E., Kautonen, T., \& Fink, M. (2014). Regional social legitimacy of entrepreneurship: Implications for entrepreneurial intention and start-up behaviour. Regional Studies, 48(6), 995-1015. Kickul, J., \& Lyons, T. S. (2012). Measuring social impact. In J. Kickul \& T. S. Lyons (Eds.), Understanding social entrepreneurship: The relentless pursuit of mission in an ever changing world (pp. 176-200). Florence, KY: Taylor \& Francis.

Kilpatrick, S., Johnson, L., King, T. J., Jackson, R., \& Jatrana, S. (2015). Making connections in a regional city: Social capital and the primary social contract. Journal of Sociology, 51(2), 207-220.

Korsgaard, S., \& Anderson, A. R. (2011). Enacting entrepreneurship as social value creation. International Small Business Journal, 29(2), 135-151. 
INTERNATIONAL JOURNAL OF ACADEMIC RESEARCH IN BUSINESS AND SOCIAL SCIENCES

Vol. 8, No. 9, Sept. 2018, E-ISSN: 2222-6990 @ 2018 HRMARS

Korsgaard, S., Müller, S., \& Tanvig, H. W. (2015). Rural entrepreneurship or entrepreneurship in the rural-between place and space. International Journal of Entrepreneurial Behavior \& Research, 21(1), 5-26.

Kroeger, A., \& Weber, C. (2014). Developing a conceptual framework for comparing social value creation. Academy of Management Review, 39(4), 513-540.

Lamprinopoulou, C., \& Tregear, A. (2011). Inter-firm relations in SME clusters and the link to marketing performance. Journal of Business \& Industrial Marketing, 26(6), 421-429.

Lan, H., Zhu, Y., Ness, D., Xing, K., \& Schneider, K. (2014). The role and characteristics of social entrepreneurs in contemporary rural cooperative development in China: case studies of rural social entrepreneurship. Asia Pacific Business Review, 20(3), 379-400.

Lang, R., \& Fink, M. (2018). Rural social entrepreneurship: The role of social capital within and across institutional levels. Journal of Rural Studies.

Lang, R., Fink, M., \& Kibler, E. (2014). Understanding place-based entrepreneurship in rural Central Europe: A comparative institutional analysis. International Small Business Journal, 32(2), 204-227.

Lautermann, C. (2013). The ambiguities of (social) value creation: towards an extended understanding of entrepreneurial value creation for society. Social Enterprise Journal, 9(2), 184-202. Lehner, O. M. (2011). Social entrepreneurship perspectives: triangulated approaches to hybridity. Jyväskylä: University of Jyväskylä.

Mair, J., \& Marti, I. (2006). Social entrepreneurship research: A source of explanation, prediction, and delight. Journal of World Business, 41(1), 36-44.

Maranville, S. (1992). Entrepreneurship in the business curriculum. Journal of Education for Business, 68(1), 27-31.

Mark, N. P., \& Harris, D. R. (2012). Roommate's race and the racial composition of white college students' ego networks. Social Science Research, 41(2), 331-342.

Mayer, S. D., Harima, A., \& Freiling, J. (2015). Network benefits for Ghanaian diaspora and returnee entrepreneurs. Entrepreneurial Business and Economics Review, 3(3), 95-121.

Mazzei, M., \& Roy, M. J. (2017). From Policy to Practice: Exploring Practitioners' Perspectives on Social Enterprise Policy Claims. VOLUNTAS: International Journal of Voluntary and Nonprofit Organizations, 28(6), 2449-2468.

McCarthy, B. (2012). From fishing and factories to cultural tourism: The role of social entrepreneurs in the construction of a new institutional field. Entrepreneurship \& Regional Development, 24(3-4), 259-282.

McKeever, E., Anderson, A., \& Jack, S. (2014). Entrepreneurship and mutuality: social capital in processes and practices. Entrepreneurship \& Regional Development, 26(5-6), 453-477.

McPherson, M., Smith-Lovin, L., \& Cook, J. M. (2001). Birds of a feather: Homophily in social networks. Annual Review of Sociology, 27(1), 415-444.

Mendoza-Abarca, K. I., \& Mellema, H. N. (2016). Aligning economic and social value creation through pay-what-you-want pricing. Journal of Social Entrepreneurship, 7(1), 101-125.

Milroy, L. (2000). Social network analysis and language change: Introduction. European Journal of English Studies, 4(3), 217-223.

Munoz, S.-A., Steiner, A., \& Farmer, J. (2014a). Processes of community-led social enterprise development: learning from the rural context. Community Development Journal, 50(3), 478-493.

Munoz, S.-A., Steiner, A., \& Farmer, J. (2014b). Processes of community-led social enterprise development: learning from the rural context. Community Development Journal, 50(3), 478-493. 
INTERNATIONAL JOURNAL OF ACADEMIC RESEARCH IN BUSINESS AND SOCIAL SCIENCES

Vol. 8, No. 9, Sept. 2018, E-ISSN: 2222-6990 @ 2018 HRMARS

Muñoz, S.-A., \& Steinerowski, A. (2012). Socially entrepreneurial skills and capabilities in a rural community context. In J. Farmer, C. Hill, \& S.-A. Muñoz (Eds.), Community Co-Production: Social Enterprise in Remote and Rural Communities (pp. 47-74). Cheltenham, UK: Edward Elgar.

Murdock, A., \& Bradburn, A. (2005). Social entrepreneurial ventures and the value of social networks. Presented at the Research of Social Enterprise Conference, Milton Keynes.

Neumeier, S. (2012). Why do social innovations in rural development matter and should they be considered more seriously in rural development research?-Proposal for a stronger focus on social innovations in rural development research. Sociologia Ruralis, 52(1), 48-69.

Nicholls, A., \& Teasdale, S. (2017). Neoliberalism by stealth? Exploring continuity and change within the UK social enterprise policy paradigm. Policy \& Politics, 45(3), 323-341.

Nordregio. (2016). Social innovation: Nordic ways of addressing the demographic shift. Stockholm, Sweden: Nordregio. Retrieved from http://www.nordregio.org/about/nordic-co-operationprogrammes/nordic-working-groups-2013-2016/demography-and-welfare/projects/social-

innovation-nordic-ways-of-addressing-the-demographic-shift/

Normann, R., \& Ramirez, R. (1993). From value chain to value constellation: Designing interactive strategy. Harvard Business Review, 71(4), 65-77.

Novy, A., Swiatek, D. C., \& Moulaert, F. (2012). Social cohesion: a conceptual and political elucidation. Urban Studies, 49(9), 1873-1889.

OECD. (1996). Networks in rural development. Paris: The Organisation for Economic Co-operation and Development.

Parker, S. C. (2018). The economics of entrepreneurship (2nd ed.). Cambridge: Cambridge University Press.

Pateman, T. (2011). Rural and urban areas: comparing lives using rural/urban classifications. Regional Trends, 43(1), 11-86.

Pearce, J., \& Kay, A. (2003). Social enterprise in anytown. Calouste Gulbenkian Foundation.

Petrov, A. N. (2008). Talent in the cold? Creative capital and the economic future of the Canadian North. Arctic, 162-176.

Phelps, C., Heidl, R., \& Wadhwa, A. (2012). Knowledge, networks, and knowledge networks: A review and research agenda. Journal of Management, 38(4), 1115-1166.

Pickernell, D., O'Sullivan, D., Senyard, J. M., \& Keast, R. L. (2007). Social capital and network building for enterprise in rural areas: Can festivals and special events contribute?

Pittaway, L., Rodriguez-Falcon, E., Aiyegbayo, O., \& King, A. (2011). The role of entrepreneurship clubs and societies in entrepreneurial learning. International Small Business Journal, 29(1), 37-57.

Pollerman, K. (2014). Processes of Cooperation in Rural Areas: Obstacles, Driving Forces, and Options for Encouragement. In E. Kasabov (Ed.), Rural Cooperation in Europe (pp. 210-227). London: Springer. Poon, J. P., Thai, D. T., \& Naybor, D. (2012). Social capital and female entrepreneurship in rural regions: Evidence from Vietnam. Applied Geography, 35(1-2), 308-315.

Putnam, R. (2000). Bowling alone: The collapse and revival of American community. New York, NY: Simon and Schuster.

Ramalingam, B., Jones, H., Reba, T., \& Young, J. (2008). Exploring the science of complexity: Ideas and implications for development and humanitarian efforts (No. 285) (pp. 1-78). Overseas Development Institute London.

Rao, H., Davis, G. F., \& Ward, A. (2000). Embeddedness, social identity and mobility: Why firms leave the NASDAQ and join the New York Stock Exchange. Administrative Science Quarterly, 45(2), 268292. 
INTERNATIONAL JOURNAL OF ACADEMIC RESEARCH IN BUSINESS AND SOCIAL SCIENCES

Vol. 8, No. 9, Sept. 2018, E-ISSN: 2222-6990 @ 2018 HRMARS

Ratten, V. (2018). Social entrepreneurship through digital communication in farming. World Journal of Entrepreneurship, Management and Sustainable Development, 14(1), 99-110.

Ray, C. (1998). Culture, intellectual property and territorial rural development. Sociologia Ruralis, 38(1), 3-20.

Razavi, S. M., Asadi, M., Esfandabadi, H. M., \& Ekbatani, H. (2014). Barriers to social entrepreneurship in Iran: an application of grounded theory. J Entrep Organ Manag, 3(2), 2-5.

Richter, R. (2017). Rural social enterprises as embedded intermediaries: The innovative power of connecting rural communities with supra-regional networks. Journal of Rural Studies.

Robinson, S., \& Stubberud, H. A. (2009). SOURCES OF ADVICE IN ENTREPRENEURSHIP: GENDER DIFFERENCES IN BUSINESS OWNERS'SOCIAL NETWORKS. International Journal of Entrepreneurship, $13,83$.

Rodríguez, S. D. A., \& Vergara-Tenorio, M. del C. (2007). Reflections on the social learning process for community work in rural areas of Mexico. The International Journal of Biodiversity Science and Management, 3(1), 31-45.

Röling, N., \& Jiggins, J. (2001). Agents in adaptive collaborative management: the logic of collective cognition. In E. Buck, C. C. Geisler, J. Schelhas, \& E. Wollenberg (Eds.), Biological diversity: balancing interests through adaptive collaborative management (pp. 145-170). Boca Raton, FL: CRC Press.

Rose, R. (2000). Policy networks in globalization: From local to cosmopolitan networking. NIRA Review, 7(1), 5-9.

Sarif, S. M., Ismail, Y., \& Sarwar, A. A. M. (2012). Availability of literature on social entrepreneurship for sustainable wealth creation in internet. International Journal of Management Research and Reviews, 2(7), 1087.

Schultz, R. (2009). Preface-social business: Designing the possibility space for social action. In J. A. Goldstein, J. K. Hazy, \& J. Silberstang (Eds.), Complexity Science and Social Entrepreneurship: Adding Social Value through Systems Thinking, ISBN (Vol. 1343683414, pp. 1-8). Litchfield Park, AZ.

Schumpeter, J. A. (1954). History of economic analysis. London: Routledge.

Sharp, J. S. (2001). Locating the community field: A study of interorganizational network structure and capacity for community action. Rural Sociology, 66(3), 403-424.

Shaw, E. (2004). Marketing in the social enterprise context: is it entrepreneurial? Qualitative Market Research: An International Journal, 7(3), 194-205.

Shedenova, N., \& Beimisheva, A. (2013). Social and economic status of urban and rural households in Kazakhstan. Procedia-Social and Behavioral Sciences, 82, 585-591.

Short, J. C., Moss, T. W., \& Lumpkin, G. T. (2009). Research in social entrepreneurship: Past contributions and future opportunities. Strategic Entrepreneurship Journal, 3(2), 161-194.

Shucksmith, M. (2010). Disintegrated rural development? Neo-endogenous rural development, planning and place-shaping in diffused power contexts. Sociologia Ruralis, 50(1), 1-14.

Sinkovics, N., Sinkovics, R. R., \& Yamin, M. (2014). The role of social value creation in business model formulation at the bottom of the pyramid-implications for MNEs? International Business Review, 23(4), 692-707.

Skerratt, S. (2013). Enhancing the analysis of rural community resilience: evidence from community land ownership. Journal of Rural Studies, 31, 36-46.

Smallbone, D., \& Welter, F. (2001). The distinctiveness of entrepreneurship in transition economies. Small Business Economics, 16(4), 249-262.

Sodhi, M. S., \& Tang, C. S. (2011). Social enterprises as supply-chain enablers for the poor. SocioEconomic Planning Sciences, 45(4), 146-153. 
INTERNATIONAL JOURNAL OF ACADEMIC RESEARCH IN BUSINESS AND SOCIAL SCIENCES

Vol. 8, No. 9, Sept. 2018, E-ISSN: 2222-6990 @ 2018 HRMARS

Srivetbodee, S., Igel, B., \& Kraisornsuthasinee, S. (2017). Creating Social Value Through Social Enterprise Marketing: Case Studies from Thailand's Food-Focused Social Entrepreneurs. Journal of Social Entrepreneurship, 8(2), 201-224.

Steiner, A., \& Atterton, J. (2015). Exploring the contribution of rural enterprises to local resilience. Journal of Rural Studies, 40, 30-45.

Steiner, A., \& Teasdale, S. (2017). Unlocking the potential of rural social enterprise. Journal of Rural Studies.

Steinerowski, A. A., \& Steinerowska-Streb, I. (2012). Can social enterprise contribute to creating sustainable rural communities? Using the lens of structuration theory to analyse the emergence of rural social enterprise. Local Economy, 27(2), 167-182.

Steinerowski, A., Jack, S. L., \& Farmer, J. (2008). Who are the Social'Entrepreneurs' and What Do They Actually Do? Presented at the Babson College Entrepreneurship Research Conference (BCERC), Frontiers of Entrepreneurship Research.

Thuesen, A. A., \& Rasmussen, H. B. (2015). Danish Rural Areas' Readiness for Joint Action as a Proxy for the Potential for Co-production. Journal of Rural and Community Development, 10(1), 32-55.

Vaarst, M. (2007). Participatory common learning in groups of dairy farmers in Uganda (FFS approach) and Danish Stable Schools (DJF Animal Sc No. 78). Aarhus: Aarhus University.

Van der Gaag, M., \& Snijders, T. A. (2004). Proposals for the measurement of individual social capital. In H. D. Flap \& B. Volker (Eds.), Creation and returns of social capital (pp. 199-218). London: Routledge.

Warren, L. (2004). Negotiating entrepreneurial identity: communities of practice and changing discourses. The International Journal of Entrepreneurship and Innovation, 5(1), 25-35.

Wasserman, S., \& Faust, K. (1994). Social network analysis: Methods and applications (Vol. 8). Cambridge, MA: Cambridge university press.

Welter, F., \& Smallbone, D. (2011). Institutional perspectives on entrepreneurial behavior in challenging environments. Journal of Small Business Management, 49(1), 107-125.

Wenger, E. (2010). Communities of practice and social learning systems: The career of a concept. In C. Blackmore (Ed.), Social learning systems and communities of practice (pp. 179-198). London: Springer.

White, S., \& Kenyon, P. (2001). Enterprise-based Youth Employment Policies, Strategies and Programmes. Geneva: ILO.

Whitelaw, S. (2012). Sustaining social organisations in rural areas. In J. Farmer, C. Hill, \& S.-A. Muñoz (Eds.), Community co-production: Social enterprise in remote and rural communities (pp. 24-46). Northampton, MA: Edward Elgar Publishing.

Woods, M. (2009). Rural geography: blurring boundaries and making connections. Progress in Human Geography, 33(6), 849-858.

Zacharakis, A. L., Meyer, G. D., \& DeCastro, J. (1999). Differing perceptions of new venture failure: a matched exploratory study of venture capitalists and entrepreneurs. Journal of Small Business Management, 37(3), 1-14.

Zahra, S. A., Gedajlovic, E., Neubaum, D. O., \& Shulman, J. M. (2009). A typology of social entrepreneurs: Motives, search processes and ethical challenges. Journal of Business Venturing, 24(5), 519-532.

Zhu, Y., Lan, H., Nees, D. A., Xing, K., Schneider, K., \& Lee, S.-H. (2015). Rural community development and the role of social entrepreneurs. In Y. Zhu, H. Lan, D. A. Nees, K. Xing, K. Schneider, S.-H. Lee, \& J. Ge (Eds.), Transforming rural communities in China and beyond (pp. 17-34). Cham: Springer. 